\title{
PENERAPAN MARKER-BASED AUGMENTED REALITY SEBAGAI MEDIA PEMBELAJARAN TATA SURYA
}

\begin{abstract}
Arya Saca
Program Studi Teknik Informatika, STIMK Nusa Mandiri

Co Responden Email: Arya.saintjohn@gmail.com

Article history

Received Nov 30, 2020

Revised Dec 11, 2020

Accepted Jan 15, 2021

Available online Feb 28, 2021

Keywords

Augmented Reality, Education,

Development

\section{Abstract}

In this era of emerging new technology. One part that can't be left behind is education. And Augmented Reality is just one of the technology that can be used to increase the quality of teaching and learning media. With the use of markerbased AR we can add interactivity to the learning medium. With the focus on the implementation of the marker-based $A R$, this research are attempting to use infographic books as the means to store the image target or marker. With the hope of introducing the readers to the implementation of Marker-based AR and showing the use of $A R$ in education. And in this research the writer found that the use of marker-based AR can give visual representation to the user using 3 dimentional object. And not just that marker-based AR are easy to develop.
\end{abstract}

\section{Riwayat}

Diterima 30 Nov 2020

Revisi 11 Des 2020

Disetujui 15 Jan 2021

Terbit 28 Feb 2021

Kata Kunci

Augmented Reality,

Pendidikan, Pengembangan
Abstrak

Dalam era perkembangan teknologi baru yang tidak ada hentinya. Salah satu bagian penting yang tidak boleh ketinggalan adalah pendidikan. Dan Augmented Reality merupakan salah satu dari banyak teknologi yang dapat digunakan untuk meningkatkan kualitas media belajar dan mengajar. Dengan menggunakan marker-based AR media kita dapat menambahkan interaktifitas pada media belajar. Dengan memfokuskan pada bentuk implementasi marker-based AR, penelitian ini bermaksud mencoba bentuk buku infografis sebagai media penyimpanan target gambar atau marker. Dengan harapan memperkenalkan pembaca mengenai implementasi AR berbasis marker-based serta memperlihatkan kegunaan AR dalam bidang edukasi. Dan dalam pengembangan aplikasi ini penulis menemukan marker-based AR dapat memberikan informasi visual tambahan kepada pemakai dengan menampilkan objek secara 3 dimensi. Tidak hanya itu marker-based AR dibilang cukup mudah untuk dikembangkan.

\section{PENDAHULUAN}

Pada abad 21 ini, teknologi merupakan bagian penting dalam kehidupan manusia. Seluruh aspek kehidupan manusiapun sudah dapat dibantu oleh teknologi. Dan salah satu aspek kehidupan manusia yang tidak boleh ketinggalan adalah pendidikan. Dan dengan memanfaatkan teknologi kita dapat meningkatkan kualitas pendidikan. "To obtain good results in the learning process, it should be supported by the appropriate media that, because the learning media is an intermediary or introduction of goo communication and fun between teachers with students." (Fakhrudin \& Yamtinah, 2017)
Augmented Reality merupakan penggambungan dunia digital dan dunia nyata, dimana lingkungan nyata akan menjadi tempat dimana objek digital berupa gambar, objek $3 \mathrm{~d}$, suara, dan lain sebagainya ditambahkan. Augmented Reality memberikan nilai interaktifitas baru dalam media pembelajaran dimana murid atau pelajar dapat melihat dan berinteraksi langsung dengan objek atau topik yang dibahas. Dan dengan menambahakan interaktifitas dalam media pembelajaran tersebut proses belajar dapat menjadi lebih efektif dan menyenangkan.

"AR can be described as the real-time combination of digital and physical information a different technological devices: in other words, it 
consists in untilizing a set of technological devices that add virtual information to the physical one, consequently implying the addition of a virtual synthetic part to what is real." (Cabero Almenara \& Barroso Osuna, 2016) Berbeda dengan virtual reality yang akan membuat lingkungan digital baru dimana kita merupakan tambahan kedalam dunia tersebut, Augmented reality menggunakan lingkungan yang sudah ada dan menambahkan benda digital. Selain itu mengembangkan Augmented Reality juga dapat dibilang lebih mudah dan lebih murah. Dengan menggunakan smartphone yang sudah dimiliki banyak orang kita sudah dapat memberikan AR-experience.

"Augmented Reality applications can complement a standard curriculum. Text, graphics, video and audio can be superimposed into students' real time environment." (Hiranyachattada \& Kusirirat, 2020) Dengan menggunakan AR kita juga dapat membantu setiap murid untuk berpartisipasi dalam sumber informasi secara langsung, dengan memberikan visualisasi obyek. Mengijinkan setiap konsep yang diterima lebih mudah dimengerti. Dan dalam pembuatan aplikasi ini Teknik pengembangan yang dipakai merupakan MarkerBased AR. Marker-Based AR merupakan penggunakan gambar statis yang berfungsi sebagai target gambar yang nantinya akan di tangkap oleh kamera smartphone untuk menampilkan obyek yang dimaksud. Penggunaan Marker-Based AR juga bermaksud untuk menggunakan implementasi buku pada target gambar. Dimana target gambar akan disimpan dalam sebuah buku infografis yang akan diisi dengan gambar target dan juga informasi mengenai objek yang digunakan. Membuat buku dan aplikasi menjadi nilai tambah satu sama lain.

Topik yang dipakai dalam aplikasi ini merupakan alam semesta, bermaksud untuk memberikan contoh implementasi dimana obyek yang ditampilkan merupakan benda yang tidak dapat dilihat langsung oleh kita di dunia nyata. Aplikasi berfungsi sebagai media yang menjebatani keterbatasan tersebut. Dan aplikasi ini akan diberikan nama SpaceAR.

\section{BAHAN DAN METODE \\ A. Design Sistem}

Metode pengembangan aplikasi yang digunakan adalah SDLC (System Development Life Cycle) model waterfall. Metode software yang bersifat sekuensial.

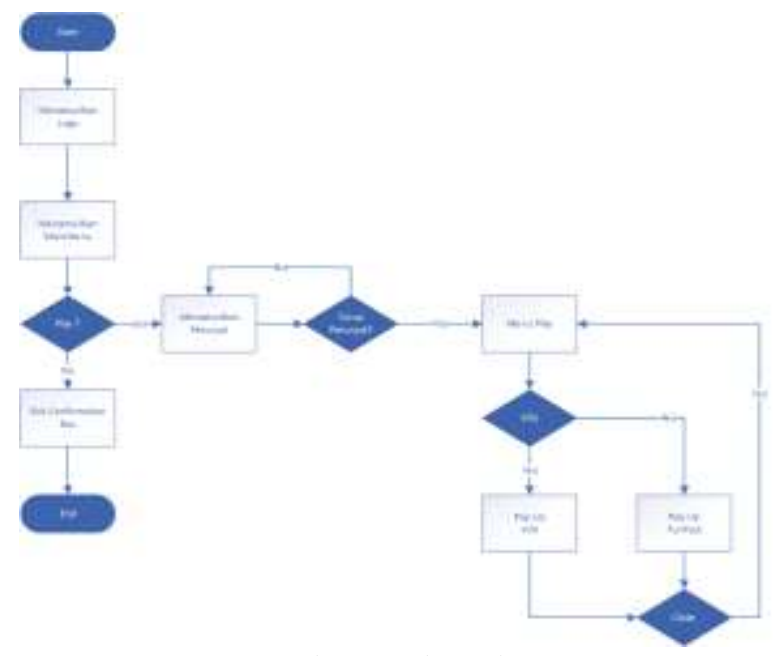

Gambar1. Flowchart

Flowhcart menggambarkan alur aplikasi yang sederhana. Infografis akan berfungsi sebagai gambar target yang akan ditangkap oleh kamera smarthphone. Dan aplikasi akan menampilkan obyek sesuai dengan target gambar yang diinginkan.

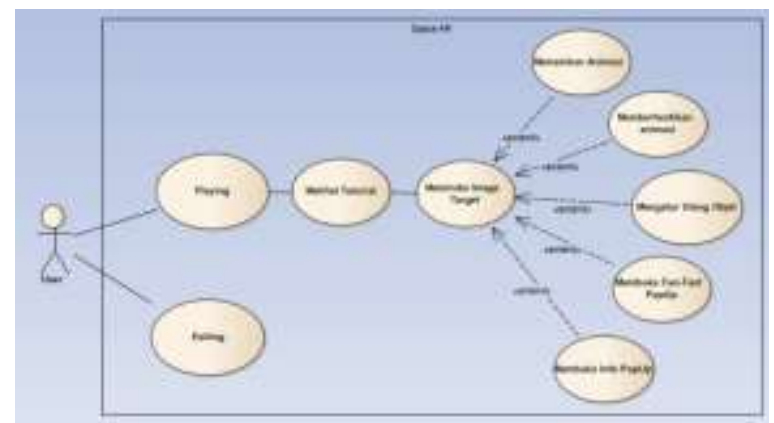

Gambar2. UseCase

Dengan penjelasan penggunaan Usecase sebagai berikut :

\begin{tabular}{|l|l|}
\hline $\begin{array}{l}\text { Use Case } \\
\text { Name }\end{array}$ & $\begin{array}{l}\text { Checkouts } \\
\text { aplikasi dapat memakai } \\
\text { menampilkan 3D objek } \\
\text { dan berinteraksi dengan } \\
\text { objek. }\end{array}$ \\
\hline Pre-Conditions & $\begin{array}{l}\text { User memiliki buku } \\
\text { berisi Image-Target }\end{array}$ \\
\hline $\begin{array}{l}\text { Post- } \\
\text { Conditions }\end{array}$ & $\begin{array}{l}\text { Aplikasi dapat } \\
\text { menampilkan objek 3D } \\
\text { sesuai dengan image- } \\
\text { target yang dipilih. }\end{array}$ \\
\hline $\begin{array}{l}\text { Failed end } \\
\text { Condition }\end{array}$ & $\begin{array}{l}\text { User tidak memiliki } \\
\text { image-target. }\end{array}$ \\
\hline Primary Actor & User \\
\hline
\end{tabular}




\begin{tabular}{|c|c|}
\hline $\begin{array}{l}\text { Main } \\
\text { Flow/Basic } \\
\text { Path }\end{array}$ & $\begin{array}{l}\text { 1. User membuka } \\
\text { aplikasi. } \\
\text { 2. User memilih play. } \\
\text { 3. User membaca } \\
\text { tutorial yang tampil. } \\
\text { Dilanjutkan dengan } \\
\text { memilih skip tutorial. } \\
\text { 4. User mengarahkan } \\
\text { kamera kepada } \\
\text { image-target yang } \\
\text { telah dipilih. } \\
\text { 5. Sistem menampilkan } \\
\text { objek 3D sesuai } \\
\text { dengan image-target } \\
\text { yang ada dan } \\
\text { menampilkan UI atau } \\
\text { tombol untuk } \\
\text { berinteraksi dengan } \\
\text { objek. } \\
\text { 6. User memilih tombol } \\
\text { info atau funfact } \\
\text { untuk mempelajari } \\
\text { informasi mengenai } \\
\text { objek yang tampil. } \\
\text { 7. Sistem menampilkan } \\
\text { informasi yang } \\
\text { tersedia mengenai } \\
\text { objek. } \\
\text { 8. User memilih tombol } \\
\text { menu untuk kembali } \\
\text { ke main menu. } \\
\text { 9. User memilih exit } \\
\text { untuk keluar aplikasi. }\end{array}$ \\
\hline
\end{tabular}

Tabel1. UseCase Checkouts

Activity diagram menggambarkan rancangan aliran kerja atau aliran aktivitas dalam aplikasi.

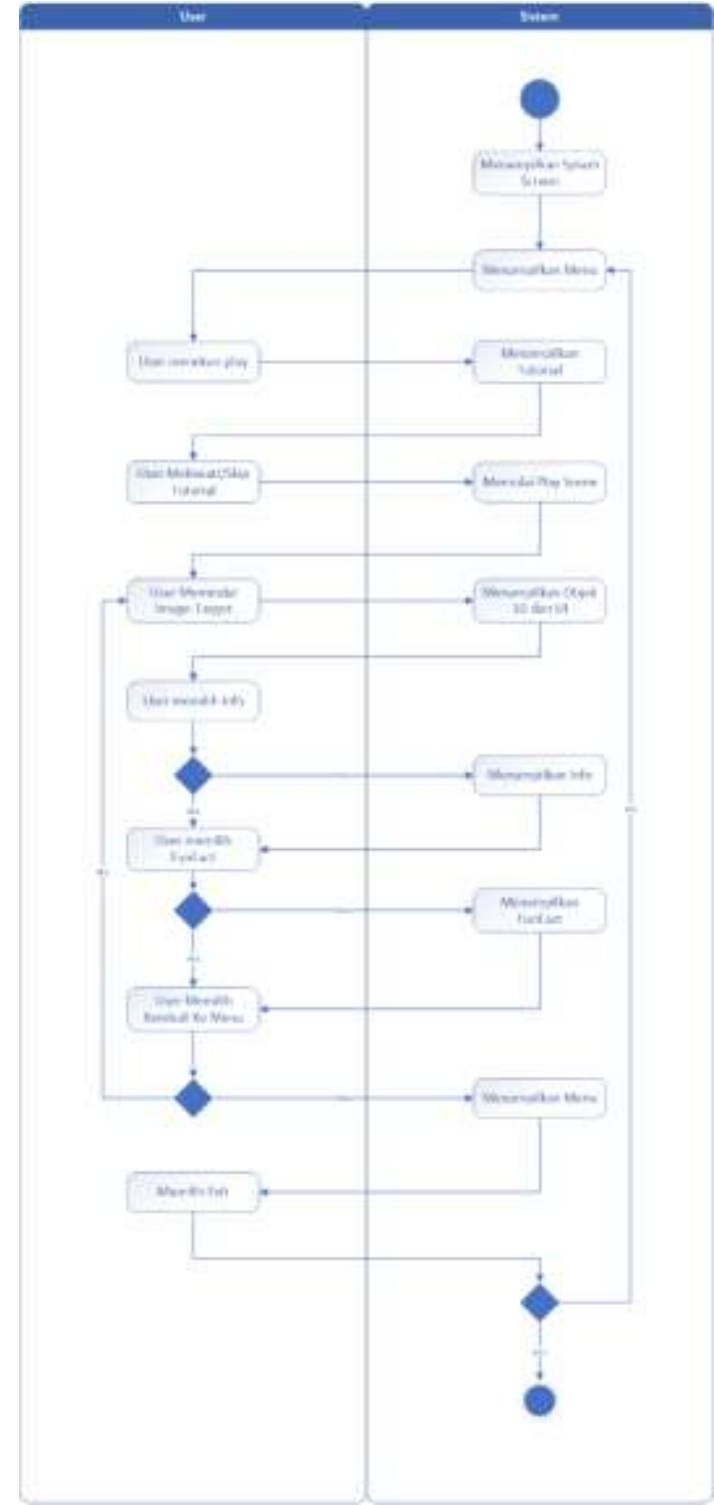

Gambar 3. Activity Diagram

Sequence diagram menggambarkan rangkaian komuniasi antar obyek yang berada di dalam aplikasi. Berikut merupakan sequence diagram SpaceAR :

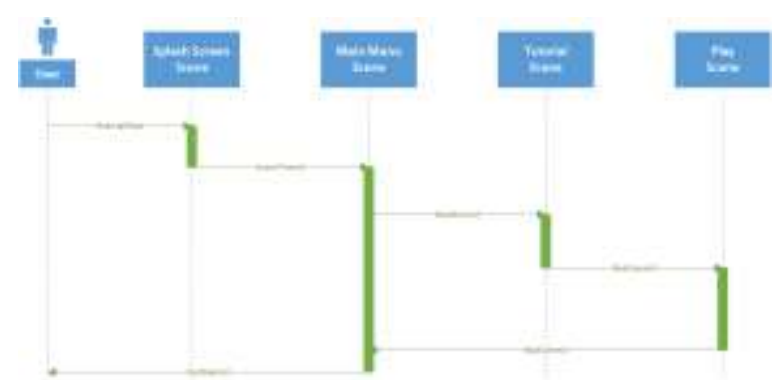

Gambar 4. Sequence Diagram 
Component diagram memperlihatkan hubungan seluruh komponen sistem. Memberikan visualisasi

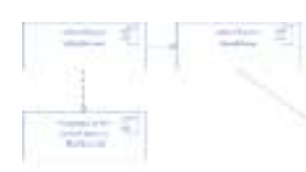

Gambar 5. Component Diagram

Dan berikut ini merupakan deployment diagram yang memperlihatkan hubungan antara hardware dan software secara visual :

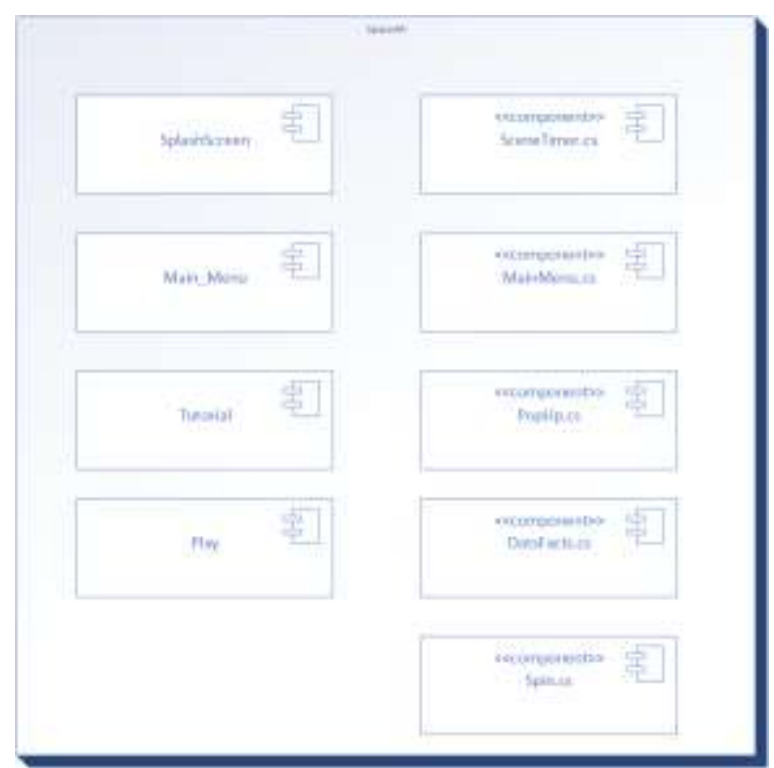

Gambar 6. Deployment Diagram

\section{B. Implementasi}

Dalam implementasi target gambar, digunakan infografis yang memuat gambar target dan juga informasi seputar obyek yang dimaksud. Dan berikut ini merupakan bentuk implementasi buku dari SpaceAR :

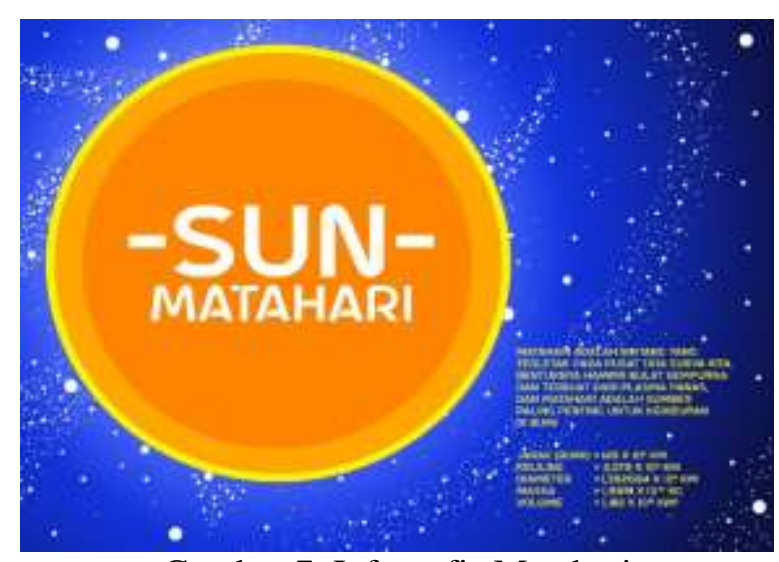

Gambar 7. Infografis Matahari

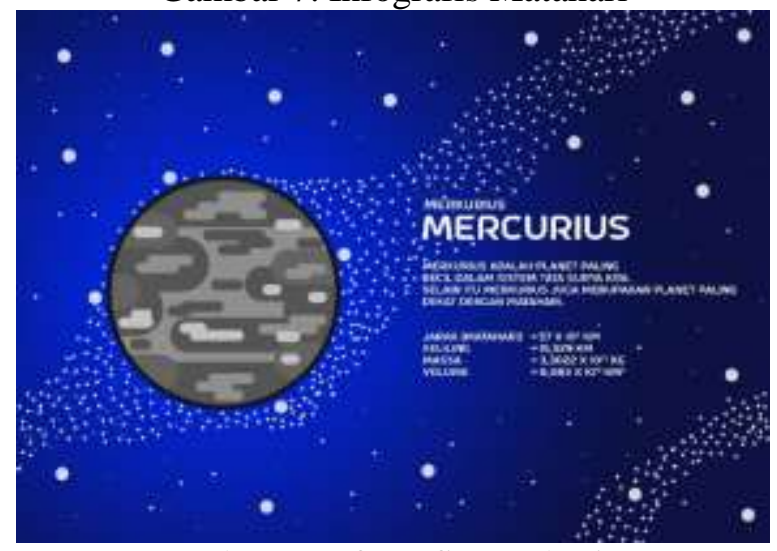

Gambar 8. Infografis Merkurius

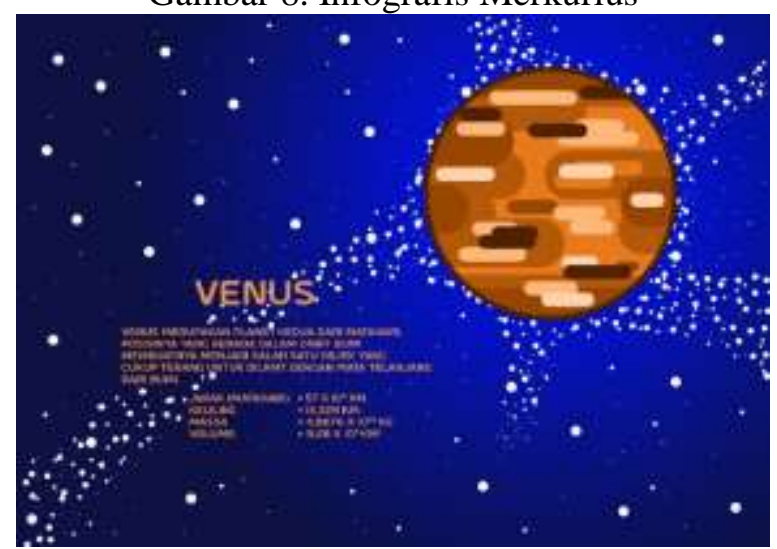

Gambar 9. Infografis Venus

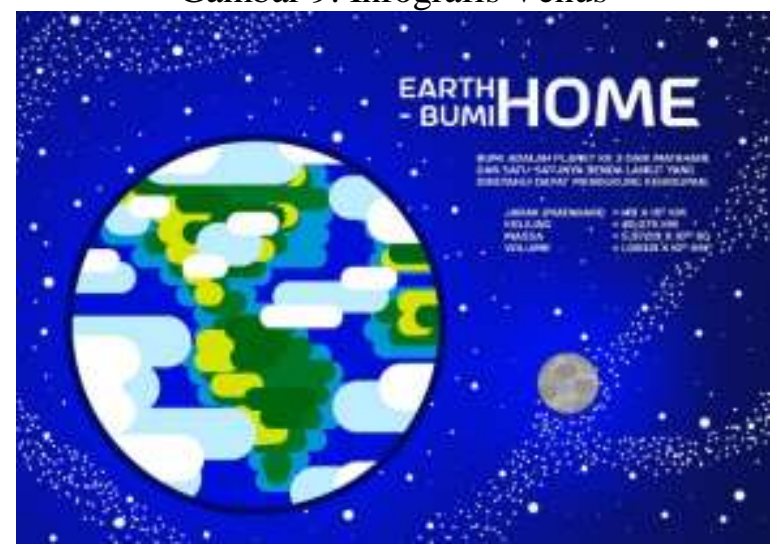

Gambar 10. Infografis Bumi 


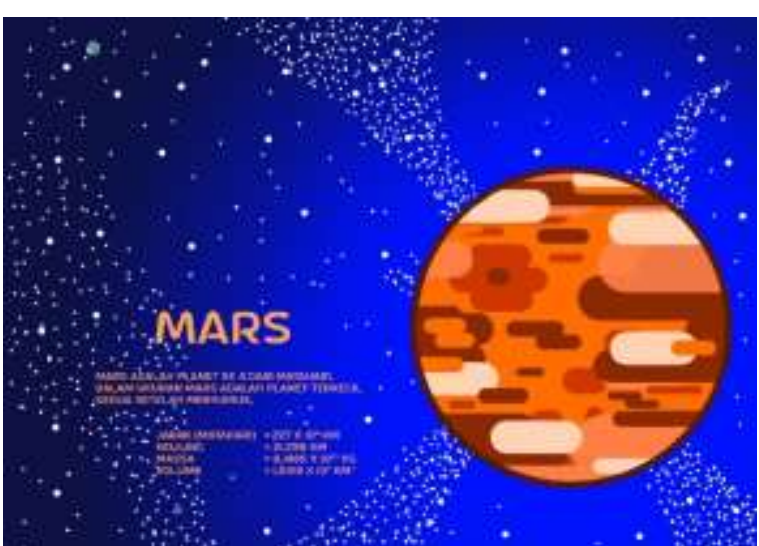

Gambar 11. Mars

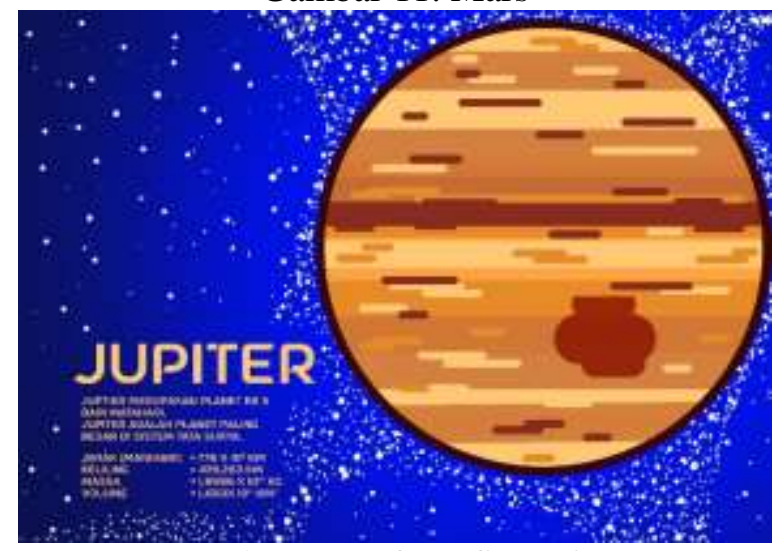

Gambar 12. Infografis Jupiter

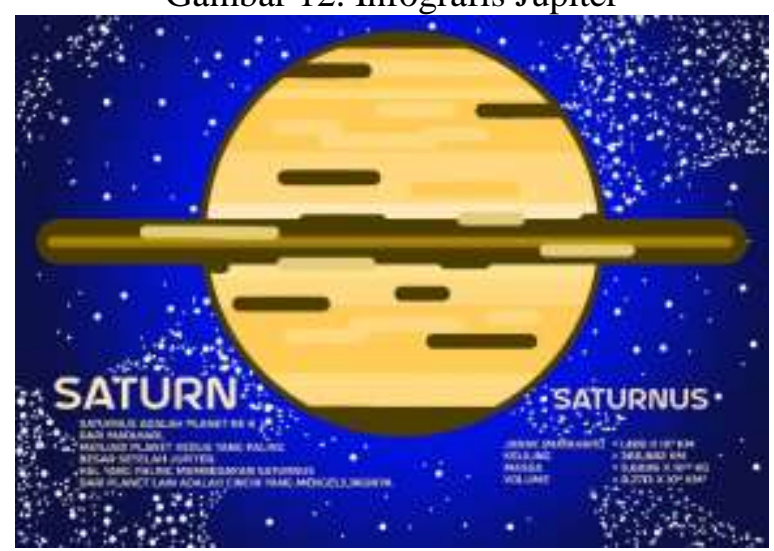

Gambar 13. Infografis Saturnus

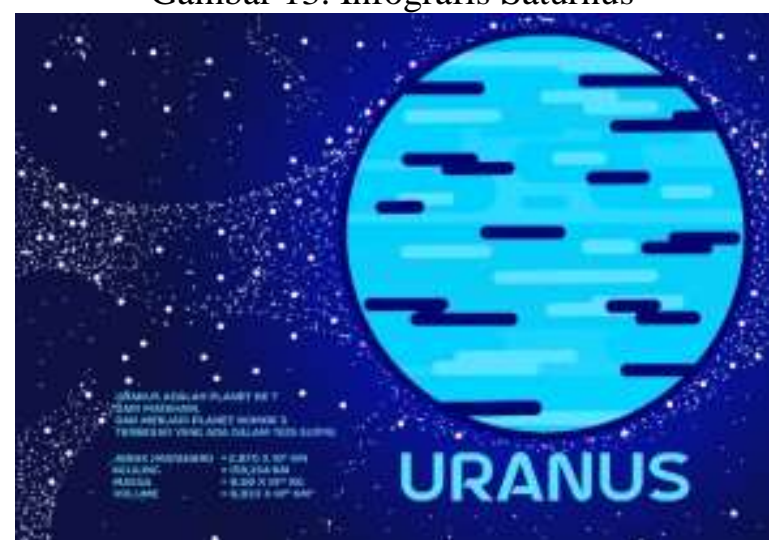

Gambar 14. Infografis Uranus

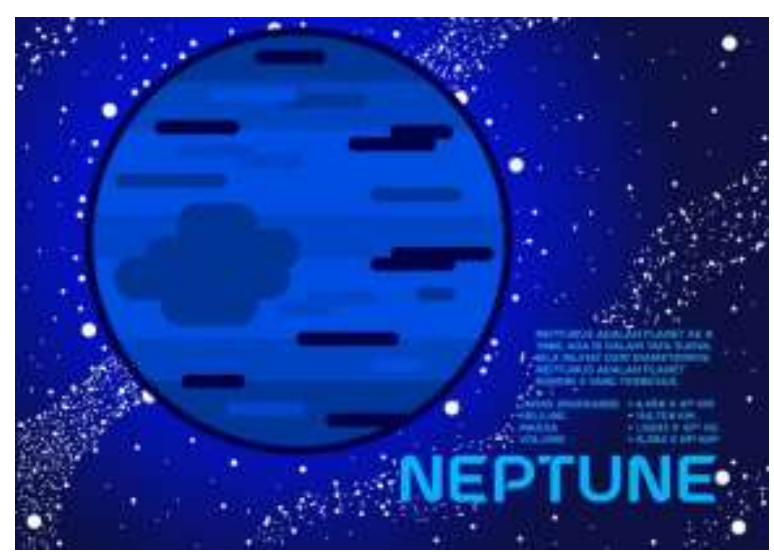

Gambar 15. Infografis Neptunus

Dalam implementasinya gambar dibuat kartun dengan design sederhana. Tidak hanya untuk menarik mata, tapi juga untuk memudahkan kamera smartphone untuk mengenali dan membaca gambar tersebut.

\section{HASIL DAN PEMBAHASAN}

\section{A. User interface}

Berikut ini merupakan tampilan UI untuk user dalam aplikasi :

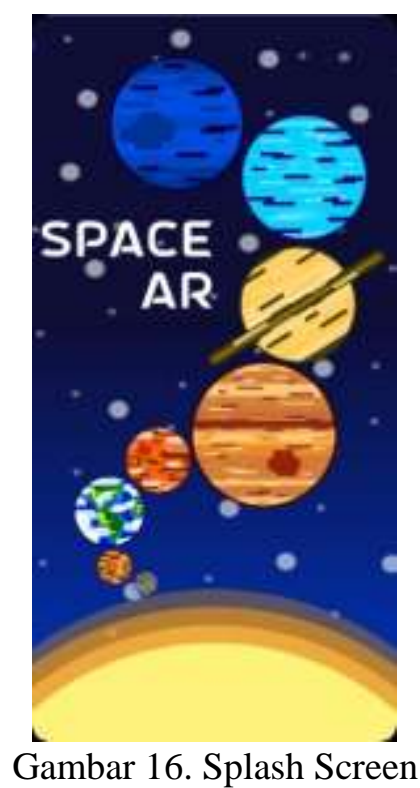




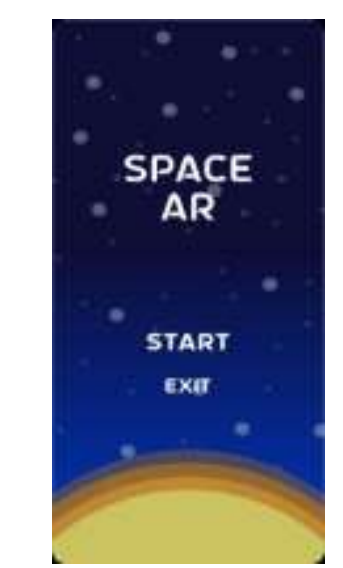

Gambar 17. Main Menu

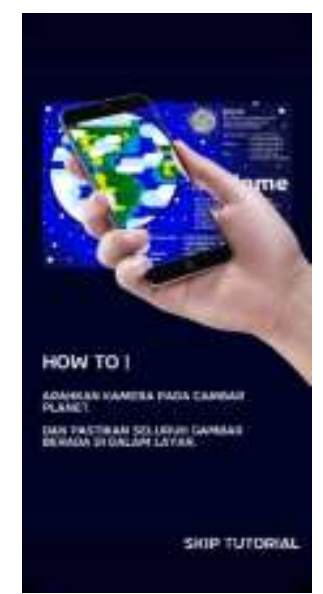

Gambar 18. Tutorial Page

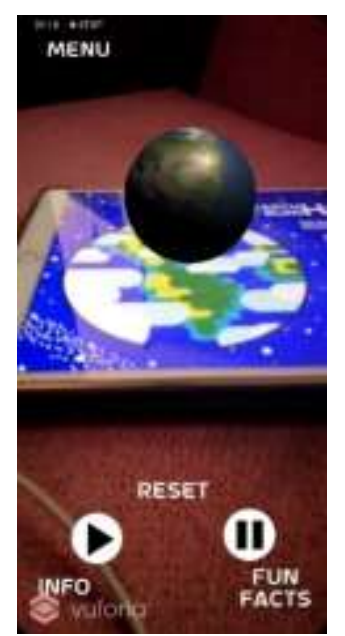

Gambar 19. Main AR Camera

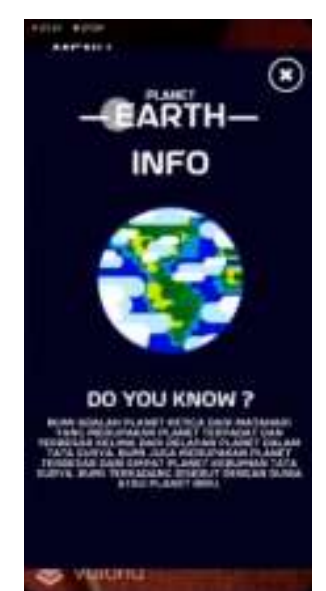

Gambar 20. Info Pop-Ups

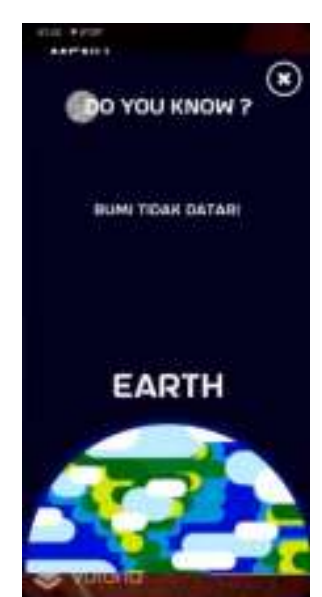

Gambar 21. FunFacts Pop-Ups

\section{B. Black Box Testing}

Dalam pengembangannya black box testing digunakan untuk menemukan bug dan melakukan testing dalam aplikasi. 


\begin{tabular}{|c|c|c|c|c|}
\hline No. & Skenario Pengujian & Hasil Yang diharapkan & $\begin{array}{l}\text { Hasil } \\
\text { Pengujian }\end{array}$ & Kesimpulan \\
\hline 1. & $\begin{array}{l}\text { Menampilkan } \\
\text { splash screen. }\end{array}$ & $\begin{array}{l}\text { Setelah menampilkan splash } \\
\text { screen selama } 5 \text { detik aplikasi } \\
\text { akan mengalihkan user ke main } \\
\text { menu. }\end{array}$ & $\begin{array}{l}\text { Sesuai } \\
\text { harapan }\end{array}$ & Valid \\
\hline 2. & $\begin{array}{l}\text { Menekan tombol } \\
\text { play untuk masuk } \\
\text { ke dalam scene } \\
\text { kamera. }\end{array}$ & $\begin{array}{l}\text { Aplikasi akan menampilkan } \\
\text { tutorial terlebih dahulu sebelum } \\
\text { masuk ke dalam scene kamera. }\end{array}$ & $\begin{array}{l}\text { Sesuai } \\
\text { harapan }\end{array}$ & Valid \\
\hline 3. & $\begin{array}{l}\text { Tampilan pertama } \\
\text { pada play scene } \\
\text { adalah kamera dan } \\
\text { tombol menu. }\end{array}$ & $\begin{array}{l}\text { Sebelum image-target di scan } \\
\text { tidak ada objek dan UI yang } \\
\text { muncul selain tombol untuk } \\
\text { kembali ke menu. }\end{array}$ & $\begin{array}{l}\text { Sesuai } \\
\text { harapan }\end{array}$ & Valid \\
\hline 4. & $\begin{array}{l}\text { Setelah image- } \\
\text { target tertangkap } \\
\text { kamera aplikasi } \\
\text { akan menampilkan } \\
\text { objek 3D dan UI } \\
\text { tombol untuk } \\
\text { berinteraksi dengan } \\
\text { objek. }\end{array}$ & $\begin{array}{l}\text { Objek 3D dan tombol UI hanya } \\
\text { akan muncul saat image-target } \\
\text { tertangkap dan berada di dalam } \\
\text { screen. Jika kamera dialihkan } \\
\text { objek dan UI akan hilang. }\end{array}$ & $\begin{array}{l}\text { Sesuai } \\
\text { harapan }\end{array}$ & Valid \\
\hline 5. & $\begin{array}{l}\text { Mencoba semua } \\
\text { image-target. }\end{array}$ & $\begin{array}{l}\text { Objek 3D dan tombol UI yang } \\
\text { tampil sesuai dengan image- } \\
\text { target pasangannya. }\end{array}$ & $\begin{array}{l}\text { Sesuai } \\
\text { harapan }\end{array}$ & Valid \\
\hline 6. & $\begin{array}{l}\text { Tombol menu akan } \\
\text { membawa user } \\
\text { kembali ke main } \\
\text { menu. }\end{array}$ & $\begin{array}{l}\text { Tombol menu membawa } \\
\text { langsung ke main menu tanpa } \\
\text { melewati splash screen terlebih } \\
\text { dahulu. }\end{array}$ & $\begin{array}{l}\text { Sesuai } \\
\text { harapan }\end{array}$ & Valid \\
\hline 7. & $\begin{array}{l}\text { Scan lebih dari } 1 \\
\text { gambar }\end{array}$ & $\begin{array}{l}\text { Sistem hanya menyediakan UI } \\
\text { untuk obyek } 3 \text { dimensi yang } \\
\text { pertama kali di scan }\end{array}$ & $\begin{array}{l}\text { Sesuai } \\
\text { harapan }\end{array}$ & Valid \\
\hline 8. & $\begin{array}{l}\text { Setelah Scan objek } \\
\text { pertama, Scan } \\
\text { objek berikutnya }\end{array}$ & $\begin{array}{l}\text { Sistem menyimpan session pada } \\
\text { objek sebelumnya dan tidak } \\
\text { mengubah session. }\end{array}$ & $\begin{array}{l}\text { Sesuai } \\
\text { harapan }\end{array}$ & Valid \\
\hline 9 . & Orientasi Aplikasi & $\begin{array}{l}\text { Orientasi tidak berubah saat } \\
\text { smartphone menjadi horizontal. }\end{array}$ & $\begin{array}{l}\text { Sesuai } \\
\text { harapan }\end{array}$ & Valid \\
\hline
\end{tabular}

Tabel 2. BlackBox Testing

\section{Support}

Dalam penggunaan aplikasi berikut merupakan spesifikasi minimum dari hardware :

\begin{tabular}{|l|l|}
\hline Kebutuhan & Spesifikasi \\
\hline
\end{tabular}

\begin{tabular}{|l|l|}
\hline Sistem Operasi & Android \\
& $\begin{array}{l}\text { Lollipop atau lebih } \\
\text { baru }\end{array}$ \\
\hline RAM & 2 GB atau lebih \\
\hline Kamera & Minimal 13 MP \\
\hline
\end{tabular}


Tabel 3. Kebutuhan hardware

\section{KESIMPULAN}

Augmented Reality memiliki potensi yang besar sebagai media pembelajara, dengan memberikan informasi tambahan secara visual dengan bantuan obyek 3 dimensi. Dimana pengguna dapat berinteraksi juga dengan obyek tersebut. Memberikan kebebasan dan peluang yang luas kepada pemakai untuk mendapatkan informasi. Dan dengan bentuk implementasi marker berbentuk buku, kita dapat memberikan nilai tambah kepada buku itu sendiri. Memberikan interaktifitas tambahan kepada media pembelajaran.

Selain itu dalam pengembangannya marker-based augmented reality juga mudah untuk dipelajari dan dipergunakan. Dan tidak membutukan tim yang besar dalam pengerjaannya. Namun untuk dapat mencakup berbagai macam mata pelajaran yang ada dibutuhkan bentuk implementasi yang berebeda-beda untuk setiap pelajaran yang ada. Seperti contoh penggunaan obyek 3 dimensi tidak dapat digunakan dalam pelajaran matematika. Sedangkan implementasi merupakan salah satu hal penting supaya informasi yang diinginkan dapat tersampaikan.

Maka dari itu, untuk dapat memanfaatkan AR dan segala potensi yang ada masih dibutuhkan banyak riset dan percobaan untuk menemukan bentuk-bentuk implementasi dari AR itu sendiri.

\section{REFERENSI}

Arief, M. A., Wibawanto, H., \& Nastiti, A. luhur. (2019). Membuat Game Augmented Reality (AR) dengan Unity 3D. Yogyakarta: Andi.

Cabero Almenara, J., \& Barroso Osuna, J. (2016). Posibilidades educativas de la Realidad Aumentada. Journal of New Approaches in Educational Research, 6(1), 44-50.

https://doi.org/10.7821/naer.2016.1.140

\author{
D.R. Robert, J. (2015). ENHANCING \\ EDUCATION THROUGH MOBILE \\ AUGMENTED REALITY. 13li- \\ Manager 's Journal of Educational \\ Technology, 11, 14.
}

Fakhrudin, A., \& Yamtinah, S. (2017). IMPLEMENTATION OF AUGMENTED REALITY TECHNOLOGY IN NATURAL SCIENCES LEARNING OF ELEMENTARY SCHOOL TO OPTIMIZE THE STUDENTS' LEARNING RESULT (Vol. 6). Retrieved from www.iojpe.org

Ghare, A. M., Khan, M. A., Rangwala, M., Kazi, S., Panwala, Prof. S., \& Salam, Prof. A. (2017). Augmented Reality for Educational Enhancement. IJARCCE, 6(3), 232-235. https://doi.org/10.17148/ijarcce.2017.635 2

Hiranyachattada, T., \& Kusirirat, K. (2020). Using mobile augmented reality to enhancing students' conceptual understanding of physically-based rendering in 3D animation. In European Journal of Science and Mathematics Education (Vol. 8).

Mustaqim, I., Pd, S. T., \& Kurniawan, N. (n.d.). PENGEMBANGAN MEDIA PEMBELAJARAN BERBASIS AUGMENTED REALITY. Retrieved from http://journal.uny.ac.id/index.php/jee/

Saltan, F., \& Arslan, Ö. (2017). The use of augmented reality in formal education: A scoping review. Eurasia Journal of Mathematics, Science and Technology Education, 13(2), 503-520. https://doi.org/10.12973/eurasia.2017.006 $28 \mathrm{a}$

Yuen, S. C.-Y., Yaoyuneyong, G., \& Johnson, E. (2011). Augmented Reality: An Overview and Five Directions for AR in Education. Journal of Educational Technology Development and Exchange, 4(1). https://doi.org/10.18785/jetde.0401.10

Zulham Adami, F., \& Budihartanti, C. (n.d.). PENERAPAN TEKNOLOGI AUGMENTED REALITY PADA MEDIA PEMBELAJARAN SISTEM PENCERNAAN BERBASIS ANDROID. 
JIKA (Jurnal Informatika) Universitas Muhammadiyah Tangerang

P ISSN : 2549-0710

Tangerang, Feb 2021, pp. 33-40

E ISSN : 2722-2713 